\title{
Places, Spaces and Bodies: Male-to-male Sex Tourism in Puerto Vallarta (Mexico)
}

\author{
By Cristóbal Mendoza*
}

\begin{abstract}
From a geographical perspective, the article focuses on the sexual encounters of men who have sex with other men for money in Puerto Vallarta (Jalisco, Mexico). In these encounters, besides money, values, ideas, stereotypes and expectations circulate between clients and sex workers. In this context it explores (i) the process of consolidation of Vallarta as a gay "place" for international tourism, (ii) the images and representations of places and bodies, particularly through the analysis of the material aspects of everyday lives of sex workers (i.e. scenarios and routines of practices), and (iii) sexualities and the body from a double perspective, as a social construction in which images and representations are exchanged and as a commercial object in the context of gay culture. The article is based on qualitative information acquired through fieldwork. Specifically, twelve semi-structured interviews were carried out with male sex workers in Old Vallarta.
\end{abstract}

\section{Places, Spaces and Bodies: Male-to-male Sex Tourism in Puerto Vallarta (Mexico) ${ }^{1}$}

Puerto Vallarta is a well-known gay-friendly tourist destination on the Mexican Pacific coast (Torres, 2006; Vidal Aldana, 2007). Moreover the city ranks second amongst the international gay destination of US nationals/visitors (Hughes, Monterrubio and Miller, 2010). ${ }^{2}$ Puerto Vallarta is located in the Northwestern part of the state of Jalisco and forms a touristic corridor in conjunction with Bahía de Banderas, in the neighboring state of Nayarit (see Figure 1). These municipalities had a joint population of 304,244 people, according to the latest official data (2005), meaning an annual population rate as high as 5\% during the period 1980-2000 (Mendoza and Medina, 2013). This growth is mainly due to the development of tourist-oriented activities from the 1970s when an alliance between local entrepreneurs and governments took place within the framework of the national policy on the development of tourist centers (Munguía, 1994).

\footnotetext{
*Professor, Metropolitan Autonomous University (UAM), Mexico.

${ }^{1} A$ previous version of this paper was presented at $10^{\text {th }}$ Annual International Conference on Tourisme, 9-12 June 2014, Athens, Greece.

“"Gay" is used as synonymous of homosexual male in the article.
} 
The profile of the average tourist in Puerto Vallarta is a 36-50 male from the USA or Canada. One out of four visitors is on his/her own in the city (Secretaría de Turismo del Gobierno de Jalisco, 2006). From original survey data, César and Arnáiz (2006) also found that they are mainly males who travel for pleasure and to rest, which are certainly distinctive characteristics of sandand-sea mass tourism. Puerto Vallarta specializes in gay tourism as more than $35 \%$ of its hotel capacity (an estimate of 18,200 rooms) being oriented towards this sector, and a high economic spill-over (an average daily expenditure of 60100 US dollars; Torres, 2006). For Mexico as a whole, the economic spill-over of the gay tourism is as high as 4.5 billion dollars annually, because this segment is mainly composed of high-income single professionals or businessmen from the US, Canada and Europe (Vidal Aldana, 2007).

Figure 1. Location of Puerto Vallarta (Jalisco) in Western Mexico

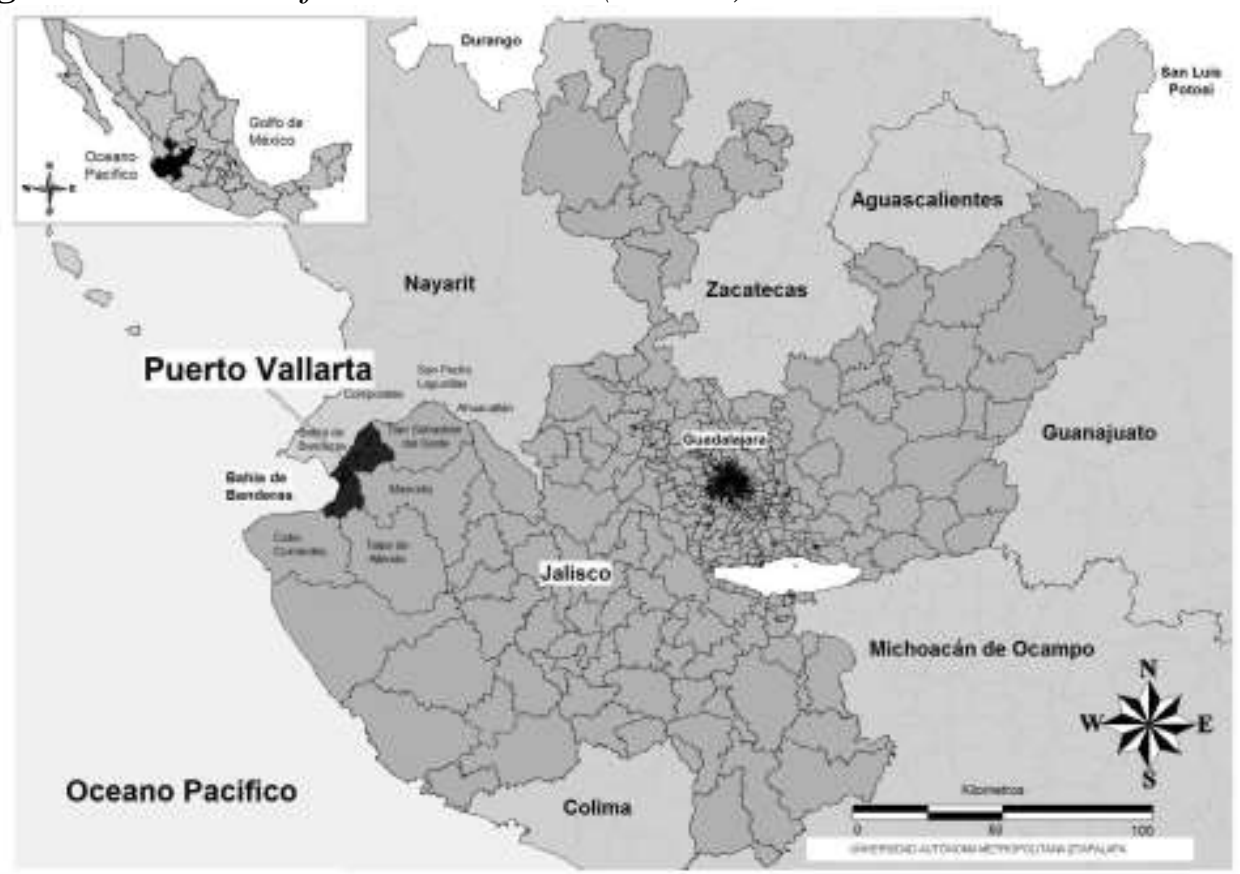

Author: Alfredo Grimaldo

The objective of this article is to analyze the reasons and motivations of a group of Mexican men to engage in sex services addressed to men in Puerto Vallarta (Mexico). In sex encounters, besides money, values, ideas, stereotypes and expectations circulate between clients and sex workers. ${ }^{1}$ Indeed, following Herold, García and DeMoya (2001), and McKercher and Bauer (2003), we explore the different layers of sex tourism that may go beyond pure monetary transaction. Indeed, literature suggests that sexual encounters may entail some kind of personal involvement on the part of both the client and the sex worker. Thus, it is anticipated that, besides money, there is a circulation of values,

\footnotetext{
${ }^{1}$ Here "sexual work", "sexual service" and "prostitution" are used without distinction. "Prostitute" though is not used in the article for its negative connotations.
} 
stereotypes, and expectations between clients and sex workers before, during, and after the sexual intercourse. Set in this context, this article explores the images and representations of places and bodies, particularly through the analysis of the spaces and times of the everyday lives of sex workers. It is also argued that, since tourism is ephemeral, it is a privileged field for the construction of new consensuses in which otherness is not as predictable as it is in other spheres of everyday life (see also Hiernaux, 2000). Indeed actors who are involved in sex tourism activities may play different roles in changing scenarios such as in Puerto Vallarta. Finally, by giving voice to sex workers, the article also considers aspects regarding sexuality and identity. Considering the shifting boundaries of Mexican male sexuality (Cantú, 2002), we also explore the idea of 'disputed, fractured sexual identities' in sex tourism (Hubbard, 2002) from the worker perspective.

From a theoretical point of view, this article is within studies of tourism which have been dominated by a positivist approach, and has paid little attention to the aspect of sexuality (Veijola and Jokinen, 1994). Moreover, Waitt, Markwell and Gorman-Murray (2008) are critical with past assumptions of heterosexuality in/and tourism studies. They claim that, even when dealing with social injustice or sexual tourism, the approach has been structural in nature and has been constructed from a middle-class heterosexual white male perspective. Recently though, there has been an emergence of research on sexuality related to tourism, specifically on sexual tourism (see, for instance, Clift and Forrest, 1999; Herold, García and DeMoya, 2001; McKercher and Bauer, 2003). For Mexico López and Van Broeck (2013) have compiled a volume of various study cases, Córdova (2010) has centered on male prostitution in the port of Veracruz; and Hughes, Monterrubio and Miller (2010) have focused on the specific case of the gay-oriented nudist beach of Zipolite (Oaxaca).

This article is based on qualitative information acquired through fieldwork. Specifically, twelve semi-structured interviews were carried out with male sex workers in Old Vallarta in October-November 2007 (Table 1). The qualitative approach is thought to be useful to gain insight into behaviors, concerns, and attitudes that are difficult to obtain in quantitative analysis. This approach seems to be the most convenient due to the difficulties in implementing more structured statistically bound survey techniques for studying gay-related issues in macho-dominated Latin American countries (see for instance FernándezDávila et al., 2008). 
Table 1. Profile of the interviewed Sex Workers

$\begin{array}{cccccc}\text { Pseudonym } & \text { Age } & \text { Place of birth } & \text { Time in P. Vallarta } & \text { Sexual Preference } & \text { Self- Definition } \\ \text { Ángelo } & 19 & \text { Comatlán, Jalisco } & 1.5 \text { years } & \text { Homosexual } & \text { Prostitute } \\ \text { Iván } & 28 & \text { Coastal village of Colima } & 1 \text { year } & \text { Bisexual } & \text { Escort } \\ \text { José Manuel } & 25 & \text { Guadalajara, Jalisco } & 4 \text { years } & \text { Homosexual } & \text { Escort } \\ \text { Carlos } & 24 & \text { Delicias, Chihuahua } & \text { Season } & \text { Bisexual } & \text { Prostitute } \\ \text { Alberto } & 17 & \text { Puerto Vallarta, Jalisco } & 2 \text { years } & \text { Homosexual/Bisexual } & \text { Prostitute } \\ \text { Fernando } & 20 & \text { Tecomán, Colima } & 5 \text { years } & \text { Heterosexual } & \text { Mayate } \\ \text { Oscar Alberto } & 25 & \text { Guadalajara, Jalisco } & 3.5 \text { years } & \text { Heterosexual } & \text { N/A } \\ \text { José } & 19 & \text { La Cruz de Loreto, Jalisco } & 3 \text { years } & \text { Bisexual } & \text { N/A } \\ \text { Johan } & 22 & \text { Distrito Federal } & \text { Season } & \text { Homosexual } & \text { Escort } \\ \text { Enrique } & 37 & \text { Guadalajara, Jalisco } & 14 \text { years } & \text { Bisexual } & \text { Masseur } \\ \text { Karla } & 22 & \text { Autlán, Jalisco } & 5 \text { years } & \text { Homosexual } & \text { Transvestite } \\ \text { Francisco } & 19 & \text { Monterrey, Nuevo León } & 5 \text { years } & \text { Bisexual } & \text { Mayate }\end{array}$

Pseudonym
Ángelo
Iván
$\mathrm{N} / \mathrm{A}=$ No answer

Current jobs

Only prostitution

Only prostitution

Prostitution. Mornings, clerical job

José Manuel

Carlos

Alberto

Fernando

Oscar Alberto

José

Johan

Enrique

Karla

Only prostitution

Prostitution. High school student

Prostitution and massage

Prostitution. Mornings, shop assistant

Only prostitution

Only prostitution

Prostitution and massage

Prostitution and dancer

Prostitution. Occasional jobs

Source: Fieldwork (October-November 2007)
Past jobs

Quesadillas stall

Dpt. of sales in hotels

Clerical jobs

Many years in prostitution No jobs

Gardener, painter, dishwasher Shops

Construction

Working on a commission basis, petrol station

Shop assistant, workshop, time-sharing sales

$$
\text { Family business }
$$

Prostitution in Colombia, plumber, construction, masseur
Encounter places

Gay clubs and beach

Gay clubs and beach

Gay clubs and Internet

Gay clubs and beach

Streets, beach, school

Gay clubs and beach

Gay clubs and beach

Gay clubs and beach

Gay clubs and beach. Internet

Gay clubs and beach

Gay clubs and streets

Gay clubs and beach. Streets

\section{Plans for the future}

Study, permanent partner, live in Guadalajara

Work in hotels or in real estate companies

Be in my current position

$$
\text { Buy a car }
$$

Get a permanent job and partner

Migrate to the US, Canada. Study, work, have a family

Have a "normal" job. Study

$$
\text { Living life }
$$

Keep on prostitution

Keep on massage

$$
\text { Be on this }
$$

"Here I'm and I haven`t quit" 
As for the fieldwork, we first identified organizations that work with sex workers. These organizations provided background information on problems that sex workers may face in the city, and they informed us about the places that male-to-male sex services took place. Second, we undertook participant observation in the places where sex services are negotiated (beach, bars, and night clubs). Through participant observation, we observed how the high density of gay-oriented businesses in Old Vallarta helps to recreate a certain gay lifestyle. We also observed the general dynamics of interactions between locals and tourists. Observations were made in October-November 2007. Following participant observation, the methodological strategy centered on the semistructured interviews. We adopted different strategies to contact sex workers. First of all, the contacted organizations introduced us to several sex workers. Second, through direct questioning of staff in gay bars and hotels, possible interviewees were identified. Third, the Internet was also used as a way of approaching sex workers. Finally, all the interviewed sex workers were also asked about possible friends who were in the sex industry. Snowballing therefore was a fourth strategy. Participants were assured that the interviews would be treated confidentially

This article first focuses on the process of consolidation of Vallarta as a destination for gay international tourism. As it will be seen later, the city is considered to be a liberating place for some interviewees who come from medium-sized or even small towns that are not very permissive with homosexual practices. Later on the paper explores spaces and temporalities of sexual tourism in Vallarta, from the study of the material aspects of everyday life (i.e. scenarios and routines of practices). In this discussion, the overlapping of the interviewees' personal and work times is pointed out. Finally, it focuses on sexualities and the body from a double perspective, as a social construction in which images and representations are exchanged and as a commercial object in the context of gay culture. The chapter ends with some final remarks.

\section{Building up a "Gay Place”: Puerto Vallarta}

Critical geographies generally describe GLT spaces as being synonymous with queer spaces, opposed to heterosexual spaces, and therefore social transgressors. Thus Binnie and Valentine (1999) reckon that the use (and even colonization) of public space by non-straight individuals in oppressive circumstances enable re-territorial processes and visibility of sexual subcultures that resist heteronormativity. Along similar lines, Alexander (quoted in Nast, 2002: 840) asserts that only a few ones want to "problematize the production of the gay marketing moment". Bassi (2006) also argues that the development of GLT-oriented businesses in Birmingham, England, and the consolidation of Asian gay nights in local clubs have had a clear positive impact on visibility of both ethnic and sexual differences in the urban context and a process of identity reaffirmation. 
Contrary to this opinion, others researchers are more critical with the supposed transgression effect of the "conquest" of urban spaces by the GLT group, and stress its market turn. For instance, Nast (2002: 836), the prologue of the special issue on queer geography in Antipode, reveals that "queer white patriarchate seemed to be everywhere: in images of queer life circulated in magazines, advertisements, and in television shows; in urban landscapes internationally and rural queer resorts in the US (...), and in a continuation of rationalized and patriarchal prerogatives". Following similar lines, Nash (2006), through her study of Toronto's gay village", mentions that the GLT movement has come to good terms to the idea of the consolidated gay-oriented residential and market neighborhood to the extent that some businesses and neighbor associations of Toronto's gay village have decided to "cleanse" this area of homeless people and sex workers. This urban area is being transformed progressively into a disciplined and controlled social and political space (Nash, 2006). Visibility and consumption have a clear impact on gay districts so that they are popular amongst tourists and a crucial part in a gentrification strategy of inner areas. Furthermore, this process of urban renewal has been incorporated into a discourse of supposed inclusive governance (see Oswin, 2008, for a review of the literature).

For Puerto Vallarta, the numerous gay clubs and bars are distinctive elements of gayness in Old Vallarta. Moreover the city offers a wide range of services to gay-friendly tourists, such as restaurants, hotels, bed and breakfast, boutiques and real estate companies. This is unique in Mexico, since although Mexico City has more nightlife to offer, it does not offer many specialized gay services (Sánchez and López, 1997). All this entertainment is highly concentrated (about a fifteen-minute walk). This constitutes an articulated identity-based network of various market relations, from consumption to exchange (see also Knopp, 1992; Bassi, 2006). Indeed Old Vallarta shows most of the characteristics of queer spaces that the literature has seen elsewhere: a high density of gay-oriented businesses, permissiveness, but restrictions out of the normative spaces. This re-creates a certain gay lifestyle which is assumed (if not searched for) by most of our interviewees.

Puerto Vallarta is an open city in which sex is a part of the tourist activities for many (either tourists or workers), as has been clarified by the interviews. Related to this, Clift and Forrest (1999), from survey data of 562 gay men in southern England, concluded that, for $29.3 \%$ of the interviewees, it was "very important" to have certain conditions to have sex on holidays (plus 35.3\% said that this was "relatively important"; Clift and Forrest, 1999). Furthermore some sex workers suggested that their entry into the sex business was very easy, not something they had sought to do, just a normal extension of the liberal atmosphere of Vallarta. The following narrative points in this direction:

I came here because I was told that life was easy here. I came here with friends, and they do the same as I do [...] at the beginning it was hard. I tried to get a normal job, but when I saw the wages, I decided to start doing this [...] A friend of mine told me that there were many tourists, and they have a lot of 
money, and they told me that prostitution was very easy here (Fernando, 20, Guadalajara, Jalisco).

This "casual" entry into prostitution is experienced in a relaxed laid-back atmosphere. Interviewees do not differentiate between spaces for work and for leisure, and between traded relationships (or even partners). An interviewee summarized this idea as follows: "I'm off today, but if something comes up...Nobody would say "no" to fresh cash" (Carlos, 24, Delicias, Chihuahua). On the other hand, the free atmosphere of Vallarta contrasts with the closed (or even hostile) atmosphere of the origin places of the interviewees who come from medium to small-sized towns in Western Mexico (see Table 1). Thus some sexual workers such as Angelo or José "fled" from the lack of tolerance in their hometowns (and from their families) regarding their sexual preferences. They define themselves as gay and believe that Vallarta is a liberating place, since they could be themselves as gay people, and escape from family bigotry.

On the whole, most of the interviewed sexual workers internalize pleasure ("they have fun"), but externalize guilty. They enjoy sex and a "gay" lifestyle, but they blame "others" (friends, foreigners, tourists, or even the city) for their entry into prostitution ("I was walking on the beach, and I was offered money for sex", José, 19, La Cruz de Loreto, Jalisco). Therefore Puerto Vallarta may be understood as a "tempting" place that seems to facilitate sexual work.

\section{Spaces And Temporalities In Sexual Tourism In Puerto Vallarta}

GLT and queer geographies have shown that specific scenarios allow (or ease) certain sexual behaviors, practices and relations. Nash and Bain (2007), for instance, proposed the concept "queering of spaces". According to their view, certain places offer the opportunity to experience alternative practices and behaviors. Similarly, Tattelman (2000) argues that queer spaces and actions imply the construction of a parallel world, filled with possibilities and pleasures that, despite being inserted into the dominant culture and values, makes possible the redefinition of fixed hetero-normative principles and the end of binary categories of sexual behavior.

Some case studies explore this matter. Thus Nash and Bain (2007), researching the exclusive women's event Pussy Palace organized in a Toronto bathhouse, reckon that this location intends to "reclaim raunch" of the participants. The event pretends to vindicate the sexuality of working women, who are supposedly more liberated than more-constricted middle-class females. For sexual tourism, Hubbard (2002) argues that the construction of interchangeable sexual identities within sex tourism can only be understood by studying how representations and experiences overlap creating identities which are fractured, disputed and in the process of change. Pointing at the same direction, Brown (2008) on his research on gay men's behavior in Easter London parks concludes that alternative sexualities are explored and 
experienced in these spaces in the immediacy of each encounter, beyond strict sexual identities.

Following this line of analysis, here we argue that the everyday life of sex workers is articulated around specific places where paid sexual activities are negotiated and carried out. As previously stated, streets are a marginal scenario for male prostitution in Puerto Vallarta. Sexual negotiations take place on the beach in the afternoon and in clubs and bars at night. The Playa de los Muertos, particularly the Blue Chairs bar and hotel (Figure 2) is a place for casual meetings in the afternoon. The place is clearly marked as being "gay", as a rainbow flag flies over the Blue Chairs hotel. Clientele comes from all ages and party expressions and affections are normal on the beach. Here, prostitution is not obvious. In fact, it would be unnoticeable at first sight. However, Blue Chairs bartenders know who are in the business, and helped us identify the possible interviewees.

This open, relaxed, laidback beach atmosphere is not seen at some Puerto Vallarta bars. The second scenery of gay sex encounters in this article is the Bar Los Amigos which is located on a downtown street in Old Vallarta. The American-style bar which is organized around a circular bar is frequented by older US and Canadian citizens; many of whom are retired and live in Mexico permanently. Even the owner who also works as a bartender is originally from the US. The poorly-lit bar has relatively cheap drinks which may attract a diverse clientele. Mexicans who enter the bar are generally young. People usually mingle easily, and physical contacts are common.

Figure 2. Blue Chairs Hotel and Bar (Playa de los Muertos)

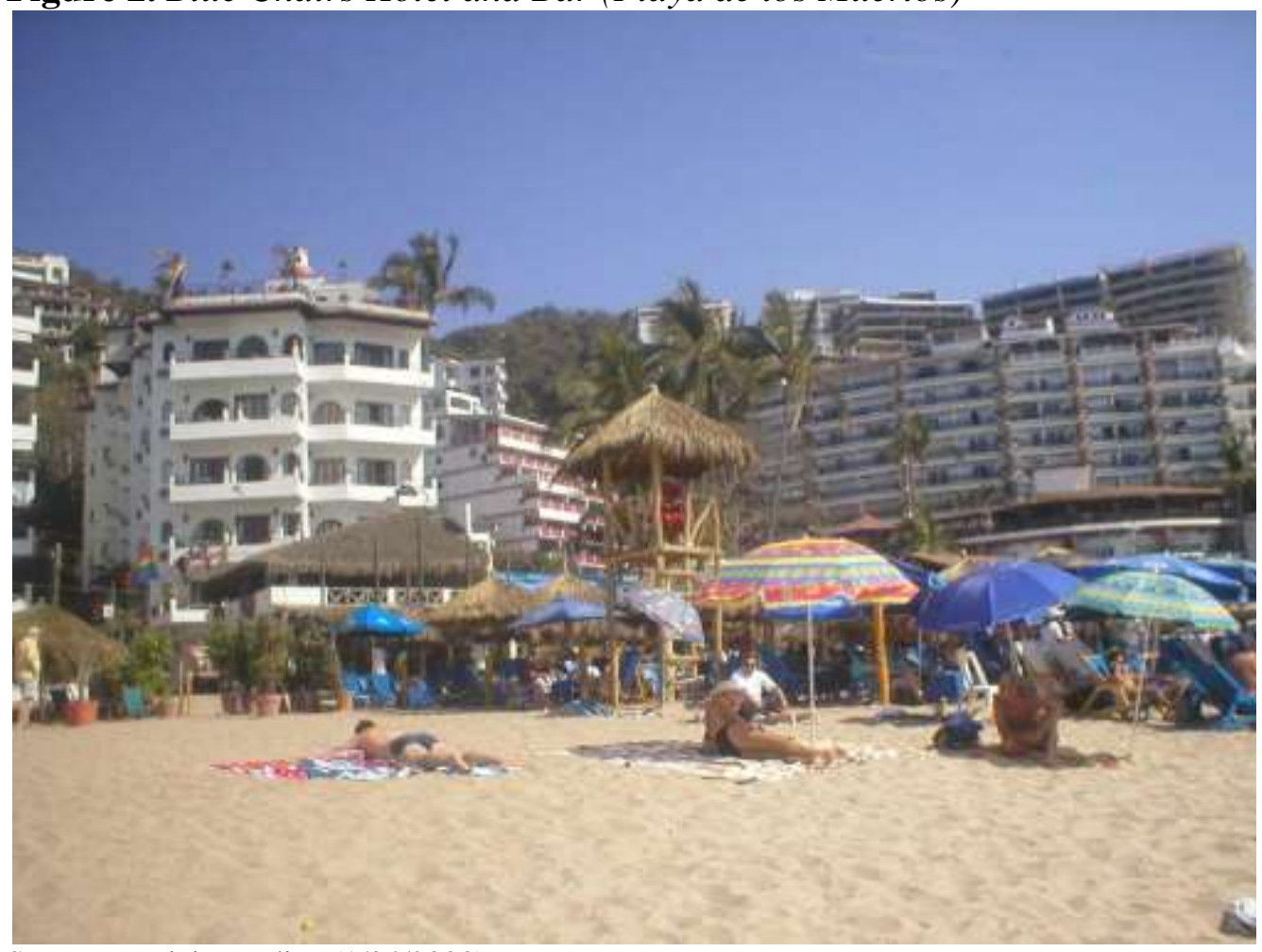

Source: Patricia Medina (1/04/2008) 
Both cases share some characteristics; easy first contacts, relaxed people and drinks. These places are permissive in terms of sexual work which is not perceived as being violent by anyone, tourists or locals, workers or businessowners. Besides the commercial transaction, these scenarios represent a way of understanding gay sexuality, apparently clear, direct and uninhibited. Beyond prostitution, these scenarios suggest that people share values and lifestyles, regardless of their age, social class or nationality (see also Altman, 1996; Hughes, 2006).

On the other hand, male prostitution follows a sort of routine as it is organized around gay tourist activities. Certainly they differ from daily routines, but, as pointed out by Hiernaux (2000), even vacation practices are reenacted according to routines and occasionally schedules. Queer geographies argue that these practices and behaviors that are repeated in specific places give way to identities (see Valentine, 1993; Hubbard, 2002; Nash and Bain, 2007)

For Puerto Vallarta, as the interviewees said, the morning is dead for business, because tourists are sleeping. Homosexual tourists spend time at the gay beach from midday (Figure 2) until 6pm. At dusk, at Blue Chairs, the bright and colorful chairs after which the bar is named are cleared off the beach. The beach is mainly for socializing. However, during the first hours of the night, prostitution takes place inside the bars associated with a mainly older clientele from the US or Canada. In these bars, flirting between older foreign men and young Mexicans is common and does not go unnoticed. Whereas night clubs have a younger clientele and sexual negotiations are more discrete The night goes on at clubs, such as Paco Paco or Mañana which were fashionable at the time this fieldwork was carried out. Finally, Puerto Vallarta has after hour party clubs that open their doors at $6 \mathrm{am}$.

This detailed description intends to show that male prostitution follows a work schedule and is articulated through specific places in Vallarta. Some interviewees, particularly the older ones, may visit all these places in search for clients in one day. As Franciso said, "we're awake all day long. It's our job. We, mayates (men who have sex with other men, but reject a gay identity), have a work schedule.

This contrasts with the carefree practices of tourists, in the context of a short holiday period. Here feelings and emotions are prone to be more visible, and people are more likely to have encounters, either sexual or not, with others (Hiernaux, 2000). Similarly, Selänniemi (2003) points out that, during holidays, people display feelings and emotions that are different in nature from those expressed on a daily basis. These "emotions" are channeled, according to Clift and Forrest (1999), though the search for sex, which is thought to be a priority for gay tourists on their holidays. In the next section, we analyze issues about the body and sexuality in greater depth. 


\section{The Body: Identity and Negotiation}

The body as a scale of analysis was introduced to the discipline of geography relatively soon after the conceptual renewal of the feminist, postcolonial and post-modern geographies (see, for instance, Grosz, 1994; Bell and Valentine, 1995). Here three dimensions of the body as well as sexuality are discussed from the GLT and queer geography perspectives. These are relevant in understanding the social constructions of the body that are exchanged and traded during sex services: (i) the heteronormativity and the (rigid) division between heterosexuality/homosexuality, (ii) the "Western" conceptions of the body and sexuality, and (iii) the redefinition of the young body in the context of a gay lifestyle. For our discussion, we also use case studies of sex tourism that analyze body representations and their role in negotiation and practices of sexual work.

Tourist studies have not taken into account post-structuralist approaches, and therefore dual hierarchies have followed suit, such as heterosexual/ homosexual (Jamal \& Hollinshead, 2001). Likewise Oswin (2008) reckons that the gay and lesbian tourist industry reproduces fixed, unitary, heteronormative market categories, and suggests that queer identities should go beyond such a duality which in turn reflects a discipline of sexual behaviors along socially accepted lines. "Heterosexualities" and "homosexualities" should be diverse enough to show a great deal of emotions and sexual practices which could be represented by different "landscapes" (Hubbard, 2002), and may imply diffuse, incomplete and multiple sexual and gender identities (Howe, 2001). This philosophy led the Toronto Women's Bathhouse Committee to welcome all types of females to their bimonthly event, including male-to-female and female-to-male transsexuals (Nash and Bain, 2007).

While conducting fieldwork, it was noticed that some interviewed sexual workers made a clear difference between their jobs and their sexual identity and preferences. Moreover, in some cases, there is a rejection of a "homosexual" identity. As seen in the literature, in countries with a strong "macho" tradition, men who penetrate other men do not think of themselves of being gay and, in general, they are not stigmatized socially, as are those who prefer a "passive" role in sexual intercourses (Carrier, 1995; Prieur, 1996, for Mexico). In this way, Alberto reacts abruptly when he believes that his sexual preference is somehow being questioned.

Because you're always, let's say, the macho, right?

Let's say, no. I'm (Iván, 28, coastal village of Colima).

Sexual identity is not an easy topic for some interviewees, and may cause personal conflicts. As an example, Fernando values his work negatively and its projection into his own identity. In his discourse, he echoes certain stereotypes (or even stigmas) that have been created by the dominant heterosexual culture (see also Mendoza and Medina, 2013). It becomes clear that not all homosexual practices imply a non-heterosexual identity. As said by Altman (1996), most people who are involved in having sex for money are not conscious of having an identity. Furthermore, it is a fact that money is a core 
concept, but it is also obvious that many people do not see themselves as being professional sex workers. This is just a job for survival (Altman, 2006). As an example of this, Fernando said in interview:

Do you fancy men or you do this only for money?

Money.

Don't you really like men?

No, actually.

But do you like men in bed, sexually? Physically are you attracted to them?

Let's say. I like when they touch me, but it is not my destiny to mingle with gay men. I don't want to do this anymore (Fernando, 20, Tecomán, Colima).

The body, age and physical conditions are key elements for sex tourism, and, on the contrary, an aged body may be a "barrier" for it (see, for instance, Altman, 1996). In our fieldwork, interviewees expressed their concerns about ageing. Indeed, men over 25 felt that they were "old" and said that they would eventually retire from prostitution. On the other hand, those tourists who felt they were old, or believed that they did not fulfill the physical characteristics in order to approach other men in bars or night clubs may have seen prostitution as an "acceptable" way of getting sex in Vallarta. According to the interviewees, clients are defined as "gringos", white, oldies (viejitos), señores. Similarly, Herold, García and DeMoya (2001) in their study of male prostitution in Santo Domingo, found that the "beach boys" preferred overweight women, 40 and over because they were the best clients.

On the contrary, the interviewees were young, in good shape, but not always athletic. Their physical characteristics may be associated with a certain idea of "dark-skinned Mexican macho". Johan was clear about this:

I'm not successful with Americans. They don't like me, because I'm light skinned. But in DF it's a whole different story (Johan, 22, Distrito Federal).

Similar to other research, our interviews point out that besides "color", clients look for a certain stereotype of the masculine Mexican male. For instance, Liguori and Aggleton (1999) conclude that sex workers in Mexico's public bathhouses not only sell their bodies, but also a male attitude. Cantú (2002) also notes that the gay male tourist industry is based on racial stereotypes of Western gay images of the "Mexican male". Following this line of thought, a sexual worker said in interview that:

What do you think that they look for in you?

Well I could say my masculinity, my body, my cock.

(Alberto, 17, Puerto Vallarta, Jalisco).

As Alberto pointed out, genitals matter as objects of desire for many tourists. Certainly, 22 year-old Johan displays a very explicit picture in which his penis is his business card on an Internet advertisement. Furthermore, in an interview, he said that "the clients look for his 22 centimeter gift". Similarly, in a study on male prostitution in Barbados and Jamaica, De Albuquerque (1998) 
concluded that penis size was relevant for female tourists who had fantasies of having sex with Black males from these islands who were supposed to be "excellent lovers".

Yet transactions are not only reduced to money and the body. Exchanges are broader than that, even if money is crucial. Thus company is sometimes sought out by some clients, with the commercial part being "hidden" in the negotiation. As examples:

When do you say that this is a business for me ....or I charge? How do you ask for money?

Look, I don't have rates. So I spend time with them and talk to them about my situation. That's it. I need to pay the rent, so I work, and they understand. In many cases there are lonely people who understand my situation and they offer to help. They value company. They want to help (José Manuel, 25, Guadalajara, Jalisco).

What do you think that they look for?

Most of them look for company.

[...] I prefer older people. I also like the way they behave. I'm more attracted to them, without vanity or arrogance. Because of their age, they are quieter, more relaxed, cleverer, and you learn more. I prefer them to a guy just like me (Iván, 28, coastal village of Colima).

Iván also introduces nuances into his narrative, when he says that "I also like the way they behave". He would rather be with a quieter, more relaxed client, no matter how old he is. In other cases, transactions are not made in a straight forward manner, but through gifts and momentary monetary help, as José Manuel said (see also Oppermann, 1999; McKercher and Bauer, 2003). As pointed out by Oppermann (1999), an interpretation of prostitution which is reduced to money does not take into account the complexity of the phenomenon of the sex tourist industry itself.

\section{Conclusions}

Sex geographies have been constructed from a Western point of view (Knopp, 1992; Nash, 2006; Bassi, 2006) and researchers on sex tourism have outlined the power relations and hierarchies that exist in the sex industry (Nast, 2002; Browne, 2006). However, following Cantús ideas (2002) on Mexico, Vallarta's sex tourism does not seem to constitute an oppressive global force, as it may be suggested in the sex tourism literature. Sex worker-client relations are based on very spatially and socially delimited encounters which are negotiated according to personal circumstances. However these are certainly framed in a particular society and culture and rooted by differences of class and origin. Even if the narratives stress "normality" (e.g. their entry to prostitution), it is obvious that sex services are needed to sustain a particular lifestyle. Yet this does not necessarily imply money for sex, but other forms of transactions (e.g. invitations or indirect payments) which are "sporadic encounters" which may last for several days. 
The relationship between sex practices and identity processes are complex in nature. For some, identity is an unfinished, ambiguous process which is contradictory to the practice of sexual services. For others, identity processes are challenging and non-conformist, coming together in a gay-friendly place. Here "boys from the countryside" (some of them openly gay, others not), with no previous contact with sexual services, go into prostitution "smoothly", "naturally", even "involuntarily". Therefore sex workers externalize guilt since they found the job without looking for it; and internalize pleasure, although this is occasionally denied.

Interviewed sex workers also show some particular behavior patterns. On the one hand, fear of old age and subsequent physical deterioration are constant in the narratives, even if many of them said that clients look for "exotism", "attitude" and "company". On the other hand, for most interviewees, prostitution is more than a job, it is a lifestyle which reproduces the gay tourist circuit, with the exception of the fact that these people charge for sex. Finally, the conjunction of private spaces, work spaces and times are of such magnitude that some interviewees do not differentiate between their professional and personal lives, interiorizing work discourses and practices, using them to narrate their relationships.

As for Puerto Vallarta, the city does not give any sort of identity to those interviewed who have a very functional view of the city. The interviewees see their living spaces as "scenarios", but they do not feel attached to them. However Puerto Vallarta allows young people from repressive backgrounds to experience their sexualities (yet this does not necessarily imply a sexual identity). This certainly needs further research; particularly what has been called "erotic subjectivities" and "spaces of desire" in recent literature (Nash and Bain, 2007; Brown, 2008).

\section{References}

Altman, D. 1996. Rupture or continuity?: The internationalization of gay identities. Social Text 14, 3, 77-94.

Bassi, C. 2006. Riding the dialectical waves of gay political economy: A story from Birmingham's commercial gay scene. Antipode 38, 2, 213-235.

Bell, D. and Valentine, G. 1995. Mapping desire: Geographies of sexualities. Routledge, London.

Binnie, J. and Valentine, G. 1999. Geographies of sexualites: A review of progress. Progress in Human Geography 23, 2, 175-187.

Brown, G. 2008. Ceramics, clothing and other bodies: affective geographies of homoerotic cruising encounters. Social \& Cultural Geography 9, 8, 915-932.

Browne, K. 2006. Challenging queer geographies. Antipode 38, 5, 885-893.

Cantú, L. 2002. De ambiente: Queer tourism and shifting boundaries of Mexican male sexualities. GLQ: A Journal of Lesbian and Gay Studies 8, 1-2, 139-166.

Carrier, J. 1995. De los otros: Intimacy and homosexuality among Mexican men. Columbia University Press, New York.

César, A. and Arnáiz, S. 2006. Bahía de Banderas a futuro: Construyendo el porvenir 2000-2025. Universidad de Guadalajara, Puerto Vallarta. 
Clift, S. and Forrest, S. 1999. Gay men and tourism: Destinations and holiday motivations. Tourism Management 20, 5, 615-625.

Córdova, R. 2010. Parallel universe: Male sex trade in public spaces of Veracruz. In Sex and the sexual during people's leisure and tourism experiences, N. Carr and Y. Poria, Eds. Cambridge Scholars Publishing, Newcastle, 35-56.

De Albuquerque, K. 1998. In search of the big bamboo. Transition 77, 1, 48-57.

Fernández-Dávila, P., Salazar, X., Cáceres, C., Maiorana, A., Kegeles, S., Coates, T. and Martínez, J. 2008. Compensated sex and sexual risk: sexual, social and economic interactions between homosexually and heterosexually-identified men of low income in two cities in Peru. Sexualities 11, 3, 352-374.

Grosz, E. 1994. Volatile bodies: Towards a corporeal feminism. Allen and Unwin, St Leonards, New South Wales.

Herold, E., García, R. and DeMoya, T. 2001. Female tourists and beach boys: Romance or sex tourism?. Annals of Tourism Research 28, 4, 978-997.

Hiernaux, D. 2000. La fuerza de lo efímero: Apuntes sobre la construcción de la vida cotidiana en el turismo. In La vida cotidiana y su espacio-temporalidad, A. Lindón, Ed. Anthropos, El Colegio Mexiquense \& Universidad Nacional Autónoma de México, Barcelona, 95-122.

Howe, A.C. 2001. Queer pilgrimage: The San Francisco homeland and identity tourism. Cultural Anthropology 16, 1, 35-61.

Hubbard, P. 2002. Sexing the Self: Geographies of engagement and encounter. Social \& Cultural Geography 3, 4, 365-381.

Hughes, H. 2006. Pink tourism: Holidays of gay men and lesbians. CABI, Washington DC.

Hughes, H., Monterrubio, J.C. and Miller, A. 2010. "Gay" Tourists and Host Community Attitudes. International Journal of Tourism Research. DOI= http:// www.interscience.wiley.com

Jamal, T. and Hollinshead, K. 2001. Tourism and the forbidden zone: The undeserved power of qualitative inquiry. Tourism Management 22, 1, 63-82.

Knopp, L. 1992. Sexuality and the spatial dynamics of capitalism. Environment and Planning D: Society and Space 10, 6, 671-689.

Liguori, A.L. and Aggleton, P. 1999. Aspects of Male Sex Work in Mexico City. In Men Who Sell Sex: International Perspectives on Male Prostitution and HIV/AIDS, P. Aggleton, Ed. Temple University Press, Philadelphia, 103-126.

López, Á. and Van Broeck, A.M. 2013. Turismo y sexo en México: Hombres que se vinculan con hombres. Una perspectiva multidisciplinaria. Universidad Nacional Autónoma de México, Mexico City.

McKercher, B. and Bauer, T.G. 2003. Conceptual framework of the nexus between tourism, romance, and sex. In Sex and Tourism: Journeys of Romance, Love, and Lust, T.G. Bauer and B. McKercher, Eds. Haworth Press, Binghamton, NY, 3-18.

Mendoza, C. and Medina, P. 2013. Turismo sexual gay en Puerto Vallarta. In Turismo y sexo en México: Hombres que se vinculan con hombres. Una perspectiva multidisciplinaria, Á. López and A.M.Van Broeck, Eds. Universidad Nacional Autónoma de México, Mexico City, 261-292.

Munguía, C. 1994. Panorama histórico de Puerto Vallarta y de la Bahía de Banderas. Secretaría de Cultura de Puerto Vallarta \& Gobierno de Jalisco, Puerto Vallarta.

Nash, C.J. 2006. Toronto's gay village (1969-1982): Plotting the politics of gay identity. The Canadian Geographer / Le Géographe canadien 50, 1, 1-16.

Nash, C.J. and Bain, A. 2007. "Reclaiming raunch"? Spatializing queer identities at Toronto women's bathhouse events. Social \& Cultural Geography 8, 1, 47-62. 
Nast, H. J. 2002. Queer patriarchies, queer racisms, international. Antipode 34, 5, 877909.

Oppermann, M. 1999. Sex tourism. Annals of Tourism Research 26, 2, 251-266.

Oswin, N. 2008. Critical geographies and the uses of sexuality: Deconstructing queer space. Progress in Human Geography 32, 1, 89-103.

Prieur, A. 1996. Domination and desire: Male homosexuality and the construction of masculinity in Mexico. In Machos, mistresses and madonnas: Contesting the power of Latin American gender imagery, M. Melhuus and K.A. Stølen, Eds. Verso, London, 83-107.

Sánchez, Á. and López, Á. 1997. Gay male places of México City. In Queers in space: Communities/ public places/ sites of resistance, G.B. Ingram, A.M. Bouthillette and Y. Retter, Eds. Bay Press, Washington DC, 197-212.

Secretaría de Turismo del Gobierno de Jalisco. 2006. Anuarios Estadísticos. Secretaría de Turismo del Gobierno de Jalisco, Guadalajara.

Selänniemi, T. 2003. On holiday in the liminoid playground: Place, time, and self in tourism. In Sex and Tourism: Journeys of Romance, Love, and Lust, T.G. Bauer and B. McKercher, Eds. Haworth Press, Binghamton, NY, 19-33.

Tattelman, I. 2000. Presenting a queer (bath)house. In Queer Frontiers: Millennial Geographies, Genders, and Generations, J.A. Boone, D. Silverman, C. Sarver, K. Quimby, M. Dupuis, M. Meeker and R. Weatherston, Eds. University of Wisconsin Press, Madison, 222-257.

Torres, A. 2006. "Se consolida Vallarta como paraíso gay en México". Anodis.com Agencia de Noticias sobre Diversidad Sexual, 9 (January 2006). DOI= http:// www.anodis.com/nota/6204.asp

Valentine, G. 1993. Hetero-sexing space: lesbian perceptions and experiences of everyday spaces. Environment and Planning D: Society and Space, 11, 4, 395413.

Veijola, S. and Jokinen, E. 1994. The body in tourism. Theory, Culture and Society $11,3,1-22$.

Vidal Aldana, A.R. 2007. Turismo gay en Puerto Vallarta: Una oportunidad para la diversificación del producto turístico. Gaceta CUC. Órgano informativo del Centro Universitario de la Costa de la Universidad de Guadalajara 48, 9-10.

Waitt, G., Markwell, K. and Gorman-Murray, A. 2008. Challenging heteronormativity in tourism studies: Locating progress. Progress in Human Geography 32, 6,781800 . 
